\title{
Epistemological Beliefs of Preservice Teachers
}

\author{
Aşkın Baydar ${ }^{1}$ \\ ${ }^{1}$ Faculty of Education, Artvin Çoruh University, Artvin, Turkey \\ Correspondence: Aşkın Baydar, Faculty of Education, Artvin Çoruh University, Artvin, Turkey. Tel: \\ 90-530-212-8131. E-mail: askinbaydar@ artvin.edu.tr
}

Received: May 10, 2020 Accepted: May 30, 2020 Online Published: June 20, 2020
doi:10.5539/hes.v10n3p44
URL: https://doi.org/10.5539/hes.v10n3p44

\begin{abstract}
This study examined the epistemological beliefs of preservice teachers, from naïve to sophisticated, from five different departments of the faculty of education in a Turkish university. By using the adapted form of the Schommer Epistemological Questionnaire, social studies, science, Turkish, mathematics, and classroom preservice teachers were surveyed and their epistemological belief levels were determined in terms of department and gender variables. Epistemological beliefs were examined in three dimensions: beliefs that pertain to learning depending on effort, beliefs that pertain to learning depending on ability, and beliefs that pertain to there being only one unchanging truth. The analysis indicated that generally all in departments, preservice teachers have sophisticated beliefs regarding the first two dimensions of the questionnaire. For the third dimension, they seem be at medium level. The results show that for the second dimension females have more sophisticated beliefs than males. For the other two dimensions there was no significant difference between females and males. A significant difference was found only for the first dimension and only between mathematics and classroom preservice teachers.
\end{abstract}

Keywords: epistemological beliefs, teacher education

\section{Introduction}

An increasing amount of research about epistemological beliefs have examined "how individuals come to know, the theories and beliefs they hold about knowing, and the manner in which such epistemological premises are a part of the cognitive processes of thinking and reasoning" (Hofer, 2000, p.378). Epistemology which can be described as "the study of what can be counted as knowledge, where knowledge is located, and how knowledge increases" (Schraw \& Olafson, 2008, p.33) is an "important area for research and may provide further insight into how individuals make meaning and how this in turn affects learning" (Hofer, 2000, p.378). The research on personal epistemology "includes beliefs about the definition of knowledge, how knowledge is constructed, how knowledge is evaluated, where knowledge resides, and how knowing occurs" (Hofer, 2001, p.355).

Almost all the existing studies on epistemological research follows Perry's studies who was one of the first researchers on personal epistemology and who investigated how college students named their educational experiences and how it changed in time (Jheng, Johnson, \& Anderson, 1993; Hofer, 2001). Perry classified epistemological beliefs in four categories. According to this classification, individuals approach knowledge with a dualistic perspective. Knowledge is true or false. Individuals see knowledge as absolute truth. Ideas are true or false, received from authority. This view generally changes when individuals realize different point of views and the possibility of uncertainty. One view can be better than another; knowledge can be ideas that come from authority, non-authority, absolute or nonabsolute resources. A change occurs from multiplism to relativism and in this step, individuals think some views are better than others. Comprehension of knowledge is probabilistic and contextual. Knowledge is constructed individually and verified with consistent resources provided by analyses and comparisons. Individuals develop a skill of shaping commitment while the development from one situation to another occurs (King, 2011), and particular ideas developed in particular contexts are more valued than the knowledge of authority (Hofer, 2000; Hofer, 2001; Tanase \& Wang, 2010). "Perry proposed that epistemological belief change is possible but synchronous; one cannot reach a higher stage by skipping any stages in between" (Tanasse \& Wang, 2010, p. 1239).

Belenky, Clinchy, Goldberger and Tarule (1986) in their study about women students' perspectives suggested another epistemological model. Belenky and her colleagues constituted a new five step categorization. Silence: 
Absolute truths are stated by external authority and women are passive, mindless and silent in the face of knowledge come from authority. Received knowledge: Women believe that they can receive and repeat but cannot produce knowledge coming from authority. Subjectivism: Distrust starts against authority. The individual understands that she can produce knowledge by herself. Procedural knowing: Knowledge is transferred and gained by objective processes. Constructed knowing: Women evaluate their views about knowledge continuously. She thinks that knowledge and truth are contextual and she can reach knowledge from both objective and subjective ways.

Baxter Magolda (1992) developed the "epistemological reflection model", on the basis of five-year longitudinal studies stated four "ways of knowing". The stages in the study are similar to Perry's. The first stage is absolute knowing. Knowledge is certain. Acquiring knowledge is important. The second stage is transitional knowing. Some knowledge is seen as uncertain and understanding knowledge becomes important. The third stage is independent knowing. Knowledge is mostly uncertain and one's own thinking is valued. The fourth stage is contextual knowing. Knowledge is determined contextually (Tanase \& Wang, 2010).

With the Reflective Judgement Model developed by King and Kitchener (1994), they investigated how students conceive knowledge and reality. In the first stages of development, individuals believe that knowledge is simple and certain. In the second stage knowledge could be uncertain and reached by both individual and authority. In the last stage knowledge is constructed contextually.

In Kuhn's (1991) Argumentative Reasoning Model found people are absolutist in their youth. Experts are the source of knowledge. In time absolutists become multiplists. Knowledge is evaluated by the human mind. Adults are evaluatists. Knowledge is uncertain and they approach by evaluating with doubt. (Buehl \& Alexander 2001; Tanase \& Wang 2010; Hofer, 2001). "Individuals may advance to evaluatist levels in some domains (truth domains), but remain at an absolutist or multiplistic level in other domains (values domains)" (Tanase \& Wang, 2010: 1239).

Different from the models up to this point, researchers Schommer Aikins (2004) proposed a system approach and a four-dimension classification for personal epistemological beliefs. In the first dimension knowledge is simple or complicated; in the second dimension knowledge is certain or uncertain; in the third dimension learning occurs instantly or in time; and in the fourth dimension learning ability is inborn and unchangeable or improvable. According to this classification "particular individuals hold multiple epistemological beliefs in different categories and they may skip conceptual stages instead of moving through a sequenced process. Thus, the personal epistemological beliefs are seen as multidimensional in their structure and asynchronous in their development" (Tanase \& Wang, 2010, p. 1239).

Epistemological beliefs that were modeled with classifications by different researchers "appear to influence comprehension and cognition for academic tasks and thus have implications for classroom academic performance" (Hofer, 2000, p. 380). "Epistemological beliefs have been found to be a predictor of academic performance with more sophisticated beliefs predicting overall grade point average" (Hofer, 2000, p. 386). These beliefs that affect learning performance and learning approaches (Schommer, Crouse, \& Rhodes, 1992) also affect teacher's beliefs, and accordingly teaching in the classroom (Doyle, 1990; Pajares, 1992). Epistemological beliefs which are complexly related with learning and achievement, are also differentiated by gender and domain (or discipline). Bendixen, Schraw, and Dunkle (1998), Demir (2005), Mason, Boldrin, and Zurlo (2006), Güven (2009), Aypay (2011), and Kessels (2013) are some researchers who investigated how epistemological beliefs differentiate by gender variable. In terms of the domain variable, college students' epistemological beliefs were generally investigated comparing social sciences with applied sciences (Karataş \& Erden, 2012), social and human sciences with engineering and economics (Jehng, Johnson, \& Anderson, 1993), or social sciences with physical sciences (Ismail, Hassan, Muhamad, Ali, \& Konting, 2013; Palmer \& Marra, 2004). King and Kitchener (1994) investigated social sciences and mathematical sciences students and Stodolsky, Salk, and Glaessner (1991) investigated $5^{\text {th }}$ grade mathematics and social studies students' epistemological beliefs. In the studies investigating pre-service teachers' epistemological beliefs, while Can and Arabacıŏglu (2009) compared science and mathematics pre-service teachers, Sünger (2007) studied only science pre-service teachers' epistemological beliefs. The most comprehensive study in the literature is Tanriverdi's (2012) research that compared classroom, mathematics, science, Turkish, English, and Early Childhood pre-service teachers' epistemological beliefs. In the present study similarly classroom, mathematics, and science departments are included. Additionally the social studies department is included.

The aim of this study is to determine epistemological beliefs of social studies, science, Turkish, mathematics, and classroom teachers in terms of gender and departments attended. The sub-questions of the research are 
constructed as follows:

1. What is the level of pre-service teachers' overall epistemological beliefs?

2. Are there differences in pre-service teachers' epistemological beliefs in terms of gender?

3. Are there differences in pre-service teachers' epistemological beliefs in terms of department?

\section{Method}

\subsection{Research Design}

This study is a descriptive survey. "Descriptive survey research aims to describe behaviors and to gather people's perceptions, opinions, attitudes, and beliefs about a current issue in education" (Lodico, Spaulding, \& Voegtle, 2010, p. 12). This study is also a relational survey. Relational surveys aim to specify the existence or degree of joint variation between two or more variables (Karasar, 2009).

\subsection{Study Group}

The data was collected from 166 pre-service teachers who attended various departments in the College of Education at Artvin Çoruh University in 2018-2019 academic year. Participation in implementations was based on volunteering. When the study group was determined, participants' genders and departments were considered. Of the participants, $62.7 \%$ were female $(n=104)$, and $37.3 \%$ were male $(n=62)$. When we look at the division of participants regarding departments, classroom pre-service teachers were in first place $(25.9 \%)$, followed by social studies (19.3\%), science pre-service teachers (18.7\%), Turkish and mathematics pre-service teachers took the last place $(18.1 \%)$.

\subsection{Data Collection Tools}

For the sociodemographic levels of the participants, a questionnaire was used and for their epistemological belief levels, the Epistemological Beliefs Questionnaire (EBQ) originally developed Schommer (1990) and named the Schommer Epistemological Questionnaire was used in the study.

\subsubsection{Schommer Epistemological Questionnaire}

To evaluate epistemological beliefs system, the Schommer Epistemological Questionnaire was developed by Schommer (1990) for college students. The original questionnaire is in English and consists of 63 items and four factors of Innate Ability, Simple Knowledge, Quick Learning, and Certain Knowledge. The questionnaire was adapted to Turkish by Deryakulu and Büyüköztürk (2002, 2005), again for college students. It consists of three factors and 34 items. The first factor "beliefs that pertain to learning depending on effort (BLDE)" consists of 18 items, the second factor "beliefs that pertain to learning depending on ability (BLDA)" consists of 9 items, and the third factor "beliefs that pertain to there being only one unchanging truth (BOUT)" consists of 7 items. Higher points indicate undeveloped, naive beliefs and lower points indicate developed, sophisticated beliefs. In validity studies for the Turkish version, at the end of confirmatory factor analysis by Deryakulu and Büyüköztürk (2005), goodness of fit indexes were $2 \div=1331.96$ (sd=524, $\mathrm{p}<.001)$, RMSEA $=0.05$, RMR $=0.09$, SRMR $=$ $0.07, \mathrm{GFI}=0.89$ and AGFI $=0.87$. Cronbach's Alpha values were found to be 0.84 (1st factor), 0.69 ( 2 nd factor), 0.64 (3rd factor), and 0.81 (overall). The values for this study are 0.78 (1st factor), 0.76 (2nd factor), 0.68 (3rd factor), and 0.79 (overall). Within this study reliability analyses of the EBQ were repeated. The overall internal validity coefficient was calculated as 0.861 . The internal consistency coefficients were found to be 0.828 for the BLDE subdimension; 0.856 for BLDA; and 0.77 for BOUT.

\subsection{Analysis of Data}

In the first step of the analysis firstly frequency and percentage distribution of the answers in questionnaire were examined. To examine if the data had normal distribution, the Kolmogorov-Smirnov test was conducted and the test applied separately for the sub-dimensions. According to Kolmogorov Smirnov test results to examine the normality distribution of the sub-dimensions, BLDE (z: 1.184), BLDA (z: 1.315), and BOUT (z: 0.869) while "p" values did not have statistically significant results $(\mathrm{p}>0.05)$. For this reason, it is understood that total scores of all three sub-dimensions have normal distribution.

To answer the first sub-question of the research, descriptive statistics values for the EBQ sub-dimensions (arithmetic mean and standard deviation) were found. To answer the second and the third sub-questions, tests of hypothesis were developed. Because the distributions are normal, parametric statistical techniques were used to tests the hypotheses. For categoric independent variables consisting of only two groups (gender) and the sample size (n) was larger than 30, an (parametric) independent sample t-test was conducted. However, (parametric) one-way analysis of variance (ANOVA) was performed when the independent variable was a categorical variable 
in more than two groups (department). Scheffe test was used as post-hoc for paired comparisons in cases when a significant difference was found with ANOVA.

\section{Results}

Arithmetic means and standard deviation values for the first sub-problem are given in Table 1 .

Table 1. Arithmetic means and standard deviation values

\begin{tabular}{llll}
\hline EBQ & n & A.M & sd \\
\hline BLDE & 166 & 35.295 & 9.256 \\
BLDA & 166 & 17.096 & 6.810 \\
BOUT & 166 & 25.915 & 7.124 \\
\hline
\end{tabular}

When we look at pre-service teachers' epistemological beliefs in terms of dimensions, for the BLDE dimension the mean is 35.295 . There are 18 items (17 negative and 1 positive) in this dimension of the questionnaire. The maximum receivable score is 90 and the minimum is 18 . If we consider that maximum receivable score is 90 in the BLDE dimension and the mean is 35.295 , pre-service teachers' beliefs that pertain to learning depending on effort is low. This subdimension's weighted average of the all items is 1.916. According to the evaluation criteria of the questionnaire, this value (1.80-2.59) means "disagree". Low scores obtained for each factor on the questionnaire show that individuals have developed, sophisticated beliefs. This means that pre-service teachers in the study group have high level of sophisticated beliefs that learning depends on effort. In the BLDA dimension, the mean is 17.915 . This subdimension's weighted average of all items is 2.44 . According to the evaluation criteria of the questionnaire, this value (1.80-2.59) means "disagree". This means pre-service teachers also have high level of sophisticated beliefs that learning depends on ability. In the BOUT dimension, the mean is 25.75. This subdimension's weighted average for all items is 2.88 . According to evaluation criteria of the questionnaire, this value (2.60-3.39) means "neutral". This means pre-service teachers have average level of beliefs about only one unchanging truth. When we use item means for the sub-dimensions as basis, the order of sub-dimensions for the study group is as follows: BLDE (1.961), BLDA (2.44), and BOUT (2.88).

An independent t-test was conducted to check if there was any difference between the gender groups (males and females) of pre-service teachers regarding their epistemological beliefs. The results of the analysis are presented in Table 2.

Table 2. T test results from comparison of pre-service teachers' epistemological beliefs mean scores in terms of gender

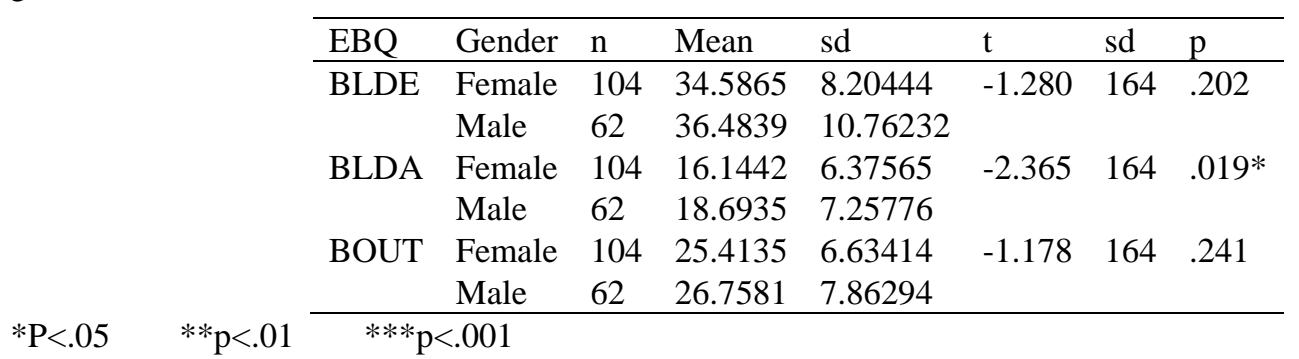

For the BDLE dimension, the mean score for females is 16.14 , and males is 18.64 . The difference between female and male pre-service teachers was statistically significant, $t(\mathrm{df})=2.37, p<.05$ (two-tailed). The gender variable explained $3.3 \%$ of the variance in the dimension of BLDA $\left(\eta^{2}=.033\right)$. According to this result, although there is no significant difference between female and male pre-service teachers in terms of BLDE and BOUT dimensions, there is a significant difference between the groups in terms of BLDA. When we look at the direction of the difference in BLDA dimension, the mean scores of male pre-service teachers are higher than females. That means female pre-service teachers have more sophisticated beliefs about only one unchanging truth than male pre-service teachers.

The differentiation statuses between epistemological levels in terms of pre-service teachers' departments were analyzed by analysis of variance ( $F$ test) and the results are given in Table 3. 
Table 3. The differences between EBQ sub-dimensions sum of mean scores for department variable (ANOVA)

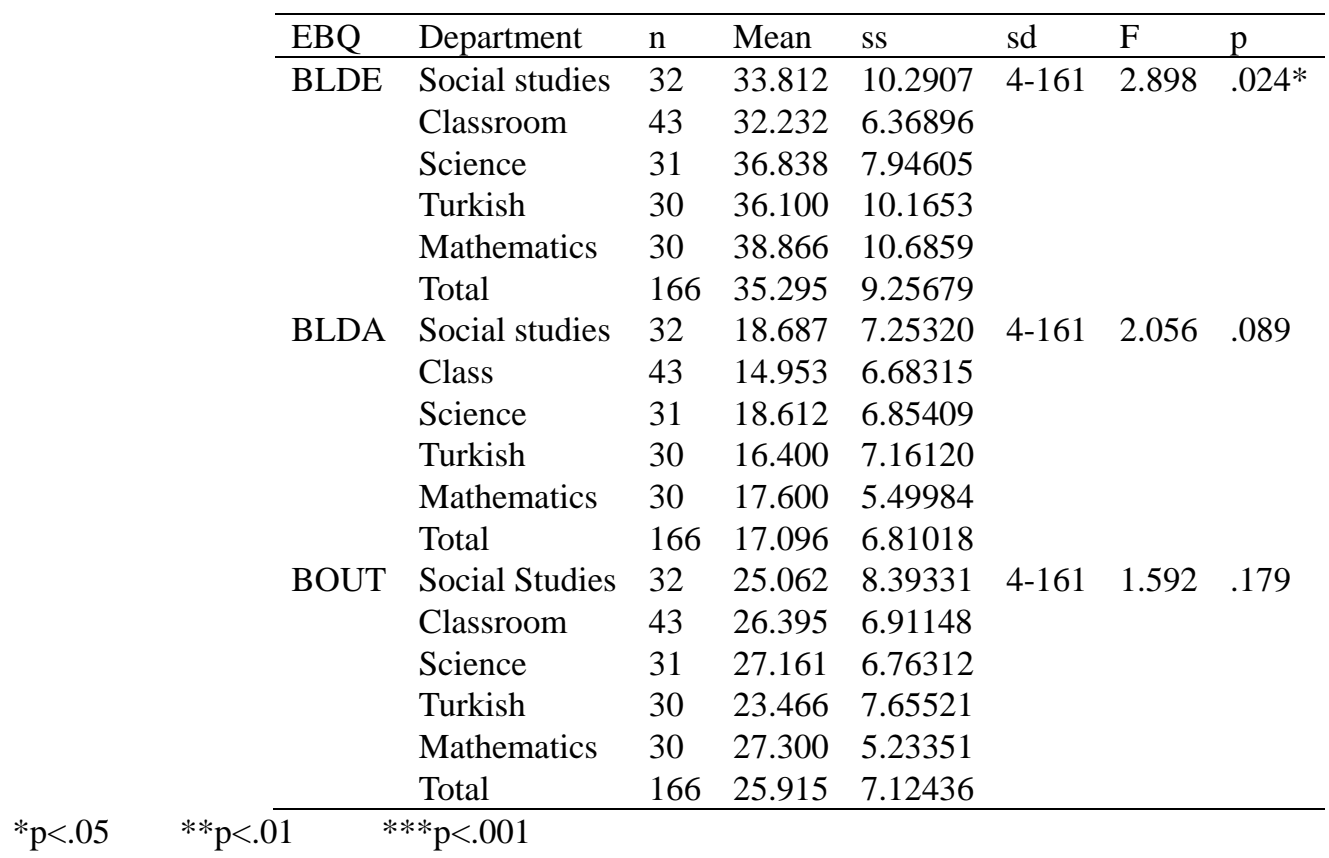

According to Table 3, for the BLDE dimension mathematics pre-service teachers have the highest mean (38.866). This is respectively followed by science (36.838), Turkish (36.100), social studies (33.812), and classroom pre-service teachers (32.232). For the department variable in BLDE, a statistically significant difference was found according to ANOVA results $\left(\mathrm{F}_{4-161}: 2.898\right.$. p: .024*). The department variable explained $3.3 \%$ of the variance in the dimension of BLDE $\left(\eta^{2}=.067\right)$. For the department variable, according to Levene's test results for variance differences in BLDE sub-dimension scores, there was no significant difference ( $p>05)$. For post-hoc techniques, the Scheffe test was used because of the homogeneity of variances.

Mean scores for BLDE sub-dimension of mathematics pre-service teachers are significantly higher than classroom pre-service teachers $(\mathrm{p}<.05)$. According to this result, classroom pre-service teachers have more sophisticated beliefs than mathematics pre-service teachers regarding BLDE.

Except for this result, there were no significant differences found for dual comparisons ( $p>.05)$.

Regarding department, the result of ANOVAS indicated that there was no significant difference between the groups in terms of BLDA F $(4,161)=2.056, \mathrm{p}=.09$ and BOUT F $(4.161)=1.592, \mathrm{p}=.179$.

\section{Discussion}

The first result of this study examining pre-service teachers' epistemological beliefs, generally all the means for participants pertain to BLDE and BLDA dimensions of the EBQ indicate sophisticated levels. On the other hand, their means pertaining to BOUT are at medium level. Similarly, in Tezci, Erdener and Atıcı's (2016) study pre-service teachers' epistemological beliefs were sorted from sophisticated to naïve, respectively, for BLDE, BLDA, and BOUT. According to Karataş and Erden's (2012) study, with undergraduate participants, the participants showed that they were at a sophisticated level by stating that they believed learning depends on effort more than it depends on ability and only one unchanging truth. The first result of the study is also similar to Çağlayan and Mehtap's (2010) study results that BLDE and BLDA of participants are more sophisticated than BOUT scores. In spite of this, according to the findings of Eroğlu and Güven's (2006) study, pre-service teachers displayed their epistemological beliefs differently with BOUT higher than the BLDE and BLDA.

The result regarding gender shows that for the BLDA dimension female participants have more sophisticated beliefs than males. For the other two dimensions, there was no significant difference between the two genders. With this result this study overlaps one-to-one with Eroğlu and Güven's (2006) study which showed that for BLDE and BLDA dimensions there were no significant differences regarding gender but for BOUT male participants had higher scores than females. In another study (Can \& Arabacioğlu, 2009) with overlapping results with this study, male pre-service teachers seem to believe learning depends on ability more than females. But there was no significant difference found for the first and third dimensions. In Oğuz's (2008) research, female 
pre-service teachers had stronger BLDE than males. This result supports our study indirectly because believing the fact that learning mostly depends on effort leads us to assume it is mostly independent of the learners' abilities.

Furthermore, this study is supported by other studies show that female participants carry more sophisticated epistemological beliefs than males (Schommer, 1993; Bendixen et al. 1998; Paulsen \& Wells, 1998; Hofer, 2000; Chai et al., 2000; Mason et al.; Aksan \& Sözer, 2007; Ismail, Hassan, Muhamad, Ali, \& Konting, 2013). Besides, some studies in the literature in contrast with this study, show that male participants carry more sophisticated epistemological beliefs than females. (King \& Kitchener, 1994; Chan, 2003; Karataş \& Erden, 2012). And in some other studies (King \& Kitchener, 1994; Chan, 2003; Karataş \& Erden, 2012). Kuhn (1991), Schommer (1993), Kuhn et al., (2000), Conley, Pintrich, Vekiri, and Harrison (2004), Strobel, Cernusca, and Jonassen (2004), Terzi (2005), Eren (2007), Sapanc1, (2012), Tanrıverdi (2012), Langcay, Gutierrez, Valencia, and Tindowen, (2019) no significant difference found between males and females.

The study's results regarding the department variable show that pre-service teachers' BLDE were sorted from naïve to sophisticated respectively for mathematics, science, Turkish, social studies, and classroom pre-service teachers. A statistically significant difference exists only in this dimension and only between mathematics and classroom pre-service teachers. In a similar study, Tanriverdi (2012) found that science pre-service teachers believe in the existence of only one truth more than classroom, mathematics, English, and early childhood pre-service teachers. In the literature, the relevant research has generally compared epistemological beliefs of social studies and science pre-service teachers. When we look at the study from this point of view, it seems that the findings are at the least in favor of social studies pre-service teachers. Thus, Jehng et al. (1993), King and Kitchener (1994), and Ismail et al.'s (2013) studies support this study. Karataş and Erden (2012) who studied the same dimensions as this study found that social sciences students have more BLDE and less BOUT than applied science students. Can and Arabacioğlu (2009) compared these three dimensions for epistemological beliefs of science and mathematics pre-service teachers and found that science pre-service teachers had more sophisticated beliefs in all three dimensions. This result of their study is similar to this study for the BLDE dimension. On the other hand, Langcay et al. (2019) found different results. According to their study, secondary pre-service teacher's epistemological beliefs were more sophisticated than primary pre-service teachers. Also, Schommer and Walker (1995) and Chan (2003) could not find any significant differences between epistemological beliefs of their participants regarding department or domain variables.

According to the first result of the study, opinions of pre-service teachers that learning depends on effort and does not depend on ability overlap with the literature in general. But the moderate level for the third dimension, similar to the research results especially conducted in Turkey, shows that our teaching education system cannot carry pre-service teachers' beliefs forward to sophisticated levels in terms of the beliefs that pertain to there being only one unchanging truth. According to the gender variable, women and men are mostly equal in worldwide studies. In several studies generally women seem epistemologically more sophisticated; in this study they exhibit more sophisticated beliefs for the second dimension. Except for this, the epistemological beliefs of women and men seem equal, as in the worldwide studies. In terms of the department variable, social departments and specifically social studies department have more sophisticated beliefs as in many other studies. But different from all other studies in the literature, classroom teaching students have the most sophisticated beliefs among the five departments in this study.

This study examined epistemological beliefs of pre-service teachers based on gender and department variables. Future studies should be conducted about the factors that affect pre-service teachers' epistemological beliefs. Moreover, the variables affecting pre-service teachers' epistemological beliefs in their prospective classes could be investigated.

\section{References}

Aksan, N., \& Sözer, M. A. (2007). Üniversite öğrencilerinin epistemolojik inançları ile problem çözme becerileri arasındaki ilişkiler. Ahi Evran Üniversitesi Kırşehir Eğitim Fakültesi Dergisi, 8(1), 31-50.

Aypay, A. (2011). Epistemolojik inançlar ölçeğinin Türkiye uyarlaması ve öğretmen adaylarının epistemolojik inançlarının incelenmesi. Eskişehir Osmangazi Üniversitesi Sosyal Bilimler Dergisi, 12(1), 1-15.

Baxter Magolda, M. B. (1992). Knowing and reasoning in college: Gender-related patterns in students' intellectual development. San Francisco: Jossey Bass.

Belenky, M. F., Clinchy, B. M., Goldberger, N. R., \& Tarule, J. M. (1986). Women's ways of knowing: The development of self, voice, and mind. New York: Basic Books. 
Bendixen, L. D., Schraw, G., \& Dunkle, M. E. (1998). Epistemic beliefs and moral reasoning. Journal of Psychology: Interdisciplinary and Applied, 132(2), 187-200. https://doi.org/10.1080/00223989809599158

Buehl, M. M., \& Alexander, P. A. (2001). Beliefs about academic knowledge, Educational Psychology Review, 13(4), 385-418. https://doi.org/10.1023/A:1011917914756

Can, B., \& Arabacıoglu, S. (2009). The observation of the teacher candidates' epistemological beliefs according to some variables. Procedia-Social and Behavioral Sciences, 1(1), 2799-2803. https://doi.org/10.1016/j.sbspro.2009.01.497

Chai, C. S., Khine, M. S., \& Teo, T. (2006). Epistemological beliefs on teaching and learning: a survey among pre- service teachers in Singapore. Educational Media International, 13(4), 285-298. https://doi.org/10.1080/09523980600926242

Chan, K. W. (2003). Hong Kong teacher education students' epistemological beliefs and approaches to learning. Research in Education, 69(1), 36-50. https://doi.org/10.7227/RIE.69.4

Conley, A. M., Pintrich, P. R., Vekiri, I., \& Harrison, D. (2004). Changes in epistemological beliefs in elementary science students. Contemporary educational psychology, 29(2), 186-204. https://doi.org/10.1016/j.cedpsych.2004.01.004

Çağlayan, S. H., \& Mehtap, B. (2010). Üniversite bayan futsal takımı sporcularının epistemolojik inançlarının bazı değişkenler açısından incelenmesi. Niğde Üniversitesi Beden Eğitimi ve Spor Bilimleri Dergisi, 4(1), $37-47$.

Demir, İ. (2005). Öğretmen adaylarının epistemolojik inançları ile otoriteryen eğilimleri arasındaki ilişkinin incelenmesi [Examining the relationship between the pre-service teachers' epistemological beliefs and their authoritarian tendencies]. Kongre Kitabı, Denizli: XIV. Ulusal Eğitim Bilimleri Kongresi Pamukkale Üniversitesi Eğitim Fakültesi 28-30 Eylül 2005(1), 730-733.

Deryakulu, D. ve Büyüköztürk, Ş. (2002). Epistemolojik inanç ölçeğinin geçerlik ve güvenirlik çalışması. Eğitim Araştırmaları, 2(8), 111-125.

Deryakulu, D., \& Büyüköztürk, Ş. (2005). Epistemolojik inanç ölçeğinin faktör yapısının yeniden incelenmesi: Cinsiyet ve öğrenim görülen program türüne göre epistemolojik inançların karşıllaştırılması. Eğitim Araştırmaları, 18, 57-70.

Doyle, W. (1990). Case methods in the education of teachers. Teacher Education Quarterly, 17(1), 7-16.

Eren, A. (2007). Examining the differences among undergraduate students' epistemological beliefs. Eğitim ve Bilim-Education and Science, 32(145), 71-84.

Eroğlu, S. E., \& Güven, K. (2006). Üniversite öğrencilerinin bilimsel epistemolojik inançlarının bazı değişkenler açışından değerlendirilmesi. Selçuk Üniversitesi Sosyal Bilimler Enstitüsü Dergisi, 16, 295-312.

Güven, M. (2009). The epistemological beliefs of distance education students. Turkish Online Journal of Distance Education, 10(3), 217-246.

Hofer, B. K. (2000). Dimensionality and disciplinary differences in personal epistemology. Contemporary Educational Psychology, 25, 378-405. https://doi.org/10.1006/ceps.1999.1026

Hofer, B. K. (2001). Personal epistemology research: Implications for learning and teaching. Educational Psychology Review, 13(4), 353-383. https://doi.org/10.1023/A:1011965830686

Ismail, H., Hassan, A., Muhamad, M. M., Ali, W. Z. W., \& Konting, M. M. (2013). Epistemological belief and learning approaches of students in higher institutions of learning in Malaysia. International Journal of Instruction, 6(1).

Jehng, J. C., Johnson, S. D., \& Anderson, R. C. (1993). Schooling and students' epistemological beliefs about learning. Contemporary Educational Psychology, 18, 23-35. https://doi.org/10.1006/ceps.1993.1004

Karasar, N. (2009). Bilimsel araştırma yöntemi. Ankara: Nobel Yayın Dağııım.

Karataş H., \& Erden, M. (2012). Profiling individual differences in undergraduates' epistemological beliefs: gender, domain and grade differences. Procedia-Social and Behavioral Sciences, 31, 738-744. https://doi.org/10.1016/j.sbspro.2011.12.133

Kessels, U. (2013). How epistemological beliefs relate to values and gender orientation. Learning and Individual Differences, 23, 256-261. https://doi.org/10.1016/j.lindif.2012.10.008 
King, B. A. (2011). Epistemological beliefs of engineering students: A comparison of educational levels and institutional type. The University of Memphis.

King, P. M., \& Kitchener, K. S. (1994). Developing reflective judgment: Understanding and promoting intellectual growth and critical thinking in adolescents and adults. San Francisco, CA: Jossey-Bass Publishers.

Kuhn, D. (1991). The skills of argument. Cambridge, UK: Cambridge University Press. https://doi.org/10.1017/CBO9780511571350

Kuhn, D., Cheney, R., \& Weinstock, M. (2000). The development of epistemological understanding. Cognitive Development, 15(3), 309-328. https://doi.org/10.1016/S0885-2014(00)00030-7

Langcay, M., Gutierrez, J. P., Valencia, M. M., \& Tindowen, D. J. (2019). Epistemological beliefs of pre-service teachers. Journal of Social Sciences and Humanities, 5(2), 37-45.

Lodico, M. G., Spaulding, D. T., \& Voegtle, K. H. (2010). Methods in educational research: From theory to practice (Vol. 28). John Wiley \& Sons.

Mason, L., Boldrin, A., \& Zurlo, G. (2006). Epistemological understanding in different judgment domains: Relationships with gender, grade level, and curriculum. International Journal of Educational Research, 45, 43-56. https://doi.org/10.1016/j.ijer.2006.08.003

Oğuz, A. (2008). Investigation of Turkish Trainee Teachers' Epistemological Beliefs. Social Behavior and personality, 36(3), 709-720. https://doi.org/10.2224/sbp.2008.36.5.709

Pajares, M. F. (1992). Teachers' beliefs and educational research: cleaning up a messy construct. Review of Educational Research, 62(3), 307-332. https://doi.org/10.3102/00346543062003307

Palmer, B., \& Marra, R. M. (2004). College student epistemological perspectives across knowledge domains: A proposed grounded theory. Higher Education, 47(3), 311-335. https://doi.org/10.1023/B:HIGH.0000016445.92289.f1

Paulsen, M. B., \& Wells, C. T. (1998). Domain differences in the epistemological beliefs of college students. Research in higher education, 39(4), 365-384. https://doi.org/10.1023/A:1018785219220

Sapancı, A. (2012). Öğretmen adaylarının epistemolojik inançları ile bilişüstü düzeylerinin akademik başarıyla ilişkisi. Celal Bayar Üniversitesi Sosyal Bilimler Dergisi, 10(1), 311-331.

Schommer, M. (1990). Effects of beliefs about the nature of knowledge on comprehension. Journal of Educational Psychology, 82(3), 498-504. https://doi.org/10.1037/0022-0663.82.3.498

Schommer-Aikins, M. (2004). Explaining the epistemological belief system: Introducing the embedded systemic model and coordinated research approach. Educational Psychologist, 39(1), 19-29.

https://doi.org/10.1207/s15326985ep3901_3

Schommer, M., Crouse, A., \& Rhodes, N. (1992). Epistemological beliefs and mathematical text comprehension: Believing it is simple does not make it so. Journal of Educational Psychology, 82, 435-443. https://doi.org/10.1037/0022-0663.84.4.435

Schommer, M. (1993). Comparisons of beliefs about the nature of knowledge and learning among postsecondary students. Research in Higher Education, 34(3), 355-370. https://doi.org/10.1007/BF00991849

Schommer, M., \& Walker, K. (1995). Are epistemological beliefs similar across domains? Journal of Educational Psychology, 87(3), 424-432. https://doi.org/10.1037/0022-0663.87.3.424

Schraw, G. J., \& Olafson, L. J. (2008). Assessing Teachers' Epistemological and Ontological Worldviews. In M. S. Khine (Ed.), Knowing, Knowledge and Beliefs. Springer, Dordrecht. https://doi.org/10.1007/978-1-4020-6596-5_2

Stodolsky, S. S., Salk, S., \& Glaessner, B. (1991). Student views about learning math and social studies. American Educational Research Journal, 28(1), 89-116. https://doi.org/10.3102/00028312028001089

Strobel, J., Cernusca, D., \& Jonassen, D. H. (2004). Different majors-different epistemological beliefs? Academic Exchange Quarterly, 12, 208-211.

Sünger, M. (2007). An analysis of efficacy beliefs, epistemological beliefs and attitudes towards science in preservice elementary science teachers and secondary science teachers. Unpublished master's thesis). Middle East Technical University, Ankara. Turkey. 
Tanase, M., \& Wang, J. (2010). Initial epistemological beliefs transformation in one teacher education classroom: Case study of four preservice teachers. Teaching and Teacher Education, 26(6), 1238-1248. https://doi.org/10.1016/j.tate.2010.02.009

Tanrıverdi, B. (2012). Pre-service teachers' epistemological beliefs and approaches to learning. Procedia-Social and Behavioral Sciences, 46, 2635-2642. https://doi.org/10.1016/j.sbspro.2012.05.538

Terzi, A. R. (2005). Üniversite öğrencilerinin bilimsel epistemolojik inançları üzerine bir araştırma. Sosyal Bilimler Dergisi, 298-311.

Tezci, E., Erdener, M. A., \& Atici, S. (2016). The Effect of Pre-Service Teachers' Epistemological Beliefs on Teaching Approaches. Universal Journal of Educational Research, 4(n12A), 205-215. https://doi.org/10.13189/ujer.2016.041326

\section{Copyrights}

Copyright for this article is retained by the author(s), with first publication rights granted to the journal.

This is an open-access article distributed under the terms and conditions of the Creative Commons Attribution license (http://creativecommons.org/licenses/by/4.0/). 